\title{
BIRC3/MALT1 Fusion Gene
}

National Cancer Institute

\section{Source}

National Cancer Institute. BIRC3/MALT1 Fusion Gene. NCI Thesaurus. Code C99875.

A fusion gene that results from a chromosomal translocation $t(11 ; 18)(q 21 ; q 21)$ which fuses the 5' portion of the BIRC3 gene to the 3' portion of the MALT1 gene. This rearrangement is associated with extra-nodal presentation of marginal zone B-cell lymphoma. 